\title{
Alpha-amylase Adsorption on Raw Starch and Its Relation to Raw Starch Digestion*
}

\author{
By R.M. SANDStedt and Seinosuke UEdA** \\ Department of Biochemistry and Nutrition, University of Nebraska, Lincoln, Nebraska 68503, U.S.A.
}

(Received for publication, November 8, 1968)

\begin{abstract}
Alpha-amylase adsorption on raw starch and its relation to raw starch digestion were investigated. Four kinds of $\alpha$-amylases - pancreatic, malt, fungal, and bacterial amylaseswere used. The relation of digestion of raw starch by $\alpha$-amylases to adsorption of the enzyme was complicated and it was dependent on the specific enzyme, its concentration, time of action and on the specific starch involved. The adsorption of the enzyme on raw starch was rapid and was desorbed at a decelerating rate with time and was similar to the digestion activity curve.
\end{abstract}

Though the enzymatic hydrolysis of raw starch is of considerable industrial and nutritional importance, few papers have been published on this subject. Blish ${ }^{2}$ and his associates at Nebraska became interested because of the need to understand the complicated amylolytic reactions which occur in bread doughs. It was necessary to develop methods for separating and determining the amylases of wheat flours and malts ${ }^{4}$ and to study their actions on the starches of wheat flour.

Gates $^{3}$ ) devised a simplified method for the study of the enzymatic digestion of raw starch and showed the vast range in ability of $\alpha$-amylases from different sources to digest raw starch. ${ }^{9}$ This method has been used for showing the differences in resistance to enzymatic digestion ${ }^{10}$ ) between various types of raw starch.

$\mathrm{Ueda}^{12}$ ) found that the amyloglucosidases of the black-koji molds also readily digest raw starch. He also found that the adsorption of these glucosidases on raw starch was related to their amylolytic action. ${ }^{13)}$

Schwimmer and Balls ${ }^{11)}$ reported that, with some exceptions, the adsorption of malt $\alpha$-amylase was related to the size of the starch granules.

Walker and Hope ${ }^{14}$ ) obtained inverse relaionships between adsorption and digestion with changes in $\mathrm{pH}$ from $\mathrm{pH} 7.8$ to $\mathrm{pH} 4.7$ and similarly with changes in temperature; adsorption decreased with increasing temperature. They state "Although adsorption does not lead to hydrolysis, and must in fact be avoided if rapid degradation of starch granules is to occur, the present experiments have indicated that the ability

* Published with the approval of the Director as Paper No. 2479 Journal Series, Nebraska Agricultural Experiment Station. Portions of this paper were reported at the September, 1960 Starch Round Table at Melvin Village, New Hampshire.

** Present address: Department of Food Science and Technology, Faculty of Agriculture, Kyushu University, Fukuoka, Japan. 
of a particular $\alpha$-amylase to digest maize-starch granules may be associated with the ability to adsorb on the granules."

The purpose of the present paper is to present further evidence concerning the adsorption of the $\alpha$-amylases on raw starch and its relation to enzymatic hydrolysis of the starch.

\section{Materials and Methods}

Enzyme sources. Enzymes from four distinct sources were used in this study: 1. Merck's commercial pancreatin. 2. Malt $\alpha$-amylase was extracted from. malted-wheat flour and purified by the procedure described by Schwimmer et. al. ${ }^{11}$ ) 3. The $\alpha$-amylase of Aspergillus oryzae was purified from "Clarase" by the method reported by Akabori et al. ${ }^{1)}$ 4. Crystalline Bacillus subtilis $\alpha$-amylase, obtained from Nagase and Co., Ltd.

Starch substrates. Wheat and rye starches were washed from doughs by the usual laboratory procedure-damaged starch was eliminated by 3 times resuspending, settling and centrifuging, each time removing the damaged starch layer. $\left.{ }^{8}\right)$

Wrinkled pea starch was prepared by the usual steeping, grinding, sieving through a 100 mesh screen and tabling.

The other starches were obtained from Corn Products Refining Corp., American Maize Products Co., National Starch and Chemical Corp., Quaker Oats Research Laboratory, and Stein, Hall and Co.

Alpha-amylase determinations. The enzyme solutions were centrifuged before standardization. The SKB method, $^{7}$ ) using a glass color-standard ${ }^{6}$ ) and Wallerstein's " $\beta$-amylase for analytical purposes," was used for determining the $\alpha$-amylase content of the enzyme preparations, for standardization of the enzyme solutions and for determination of the $\alpha$-amylase content of the filtrates from the digests. This method was specifically designed for the determination of $\alpha$-amylase in the presence of $\beta$ amylase, is standard ${ }^{5}$ ) for determining $\alpha$-amylase in malts and is widely used for determining $\alpha$-amylase in other $\alpha$-amylase preparations. Alpha-amylase units as used in this paper are SKB units.

Determination of raw starch digestion. The method used was a modification of the method described by Gates et $a l .{ }^{3}$ ) $\quad$ To facilitate operation the constituents for the determination were added as aliquots of solutions. The starch was made up in suspension in a ratio of $400 \mathrm{mg}$ starch to $4 \mathrm{ml}, 5 \mathrm{ml}$ or $10 \mathrm{ml}$ of water. A $4 \mathrm{ml}$ aliquot would contain $375 \mathrm{mg}$ of starch and $3.75 \mathrm{ml}$ of water; a $10 \mathrm{ml}$ aliquot would contain $390 \mathrm{mg}$ starch and $9.70 \mathrm{ml}$ of water. When taking aliquots, the starch was kept in suspension with a magnetic stirrer.

The composition of the digestion mixture was varied as desired in quantity of starch and in $\alpha$-amylase concentration. The constant constituenț wẹre; 
$1 \mathrm{ml}$ of $1 . \mathrm{M}$-acetate buffer of desired $\mathrm{pH}$

$2 \mathrm{ml}$ of $2 \%$ gelatin- $0.2 \% \mathrm{CaCl}_{2}$ solution*

$0.25 \mathrm{ml}$ (approximate) chloroform*

water to make $15 \mathrm{ml}$

The digestions took place in a shaker-type water bath at $30^{\circ} \mathrm{C}$ with constant mild shaking (just sufficient to prevent starch settling) for the desired digestion period. The digests were filtered by suction through tared stainless-steel filter crucibles $(5 \mu$ pore size), dried and weighed. The loss in weight (starch in the control minus starch from the digest) is the measure of digestion or of enzyme activity. The amylase was determined in an aliquot of the filtrate and the adsorbed enzyme calculated by subtraction from the enzyme in the control with no starch. Controls on starch and on enzyme were run at the start and end of each series.

\section{Results and Discussion}

The data obtained by the application of the above methods may be presented in many ways in order to show the course of digestion, of enzyme adsorption and their complicated interrelations.

Comparative digestion and adsorption by pancreatic $\alpha$-amylase

Fig. 1 shows the course of adsorption and digestion of $363 \mathrm{mg}$ of raw maize starch by $25.7 \mathrm{SKB}$ units of pancreatic $\alpha$-amylase covering a $20 \mathrm{hr}$ period. The starch remaining undigested after each interval of digestion time is shown in curve 1. These data also may be plotted as shown in curve 2; data of curve 1 subtracted from the $363 \mathrm{mg}$ found in the control. Curve 2 also may be considered as representing the accumulation of end-product oligosaccharides. The $\alpha$-amylase found in the filtrate, at the periods of time varying from $6 \mathrm{~min}$ to $20 \mathrm{hrs}$, is shown in curve 3 . The values for adsorbed enzyme are shown in curve 4 ; the units of enzyme of curve 3 subtracted from the 25.7 units found in the control.

The adsorption is rapid as shown in curve 3 by the drop from 25.7 units to 8 units in $10 \mathrm{~min}$. Actually the adsorption under these conditions is complete in less than $30 \mathrm{sec}^{* *}$ and is then desorbed at a decelerating rate as shown in curve 4 of Fig. 1. A comparison of the decelerating curve 4 with the accelerating curve 2 suggests the possibility of the end-products causing the desorption.

The data of Fig. 1 curve 1 may be recalculated and plotted as a rate of digestion curve (mg of starch digested per hour). For comparative purposes, in Fig. 2, the rate of digestion (curve 1) is shown with the amylase adsorption-desorption

* Previous research by R. M. Sandstedt, Dona Strahan and Muhammad Sherif under U.S.D.A. Northern Utilization Research Contract 12-14-100-470 (71) showed a saturated solution of chloroform to be an excellent inhibitor of microorganism growth for $\alpha$-amylase studies involving extended time periods of enzyme activity. However, in excess with agitation, chloroform became an effective surface-active enzyme inactivator. Gelatin, in proper amount, was found to completely protect the the enzyme against this surface denaturation. The calcium ion protects the enzyme from deterioration while in solution during action. ${ }^{4)}$

** Recent data obtained by B. D. Hites of this laboratory. 


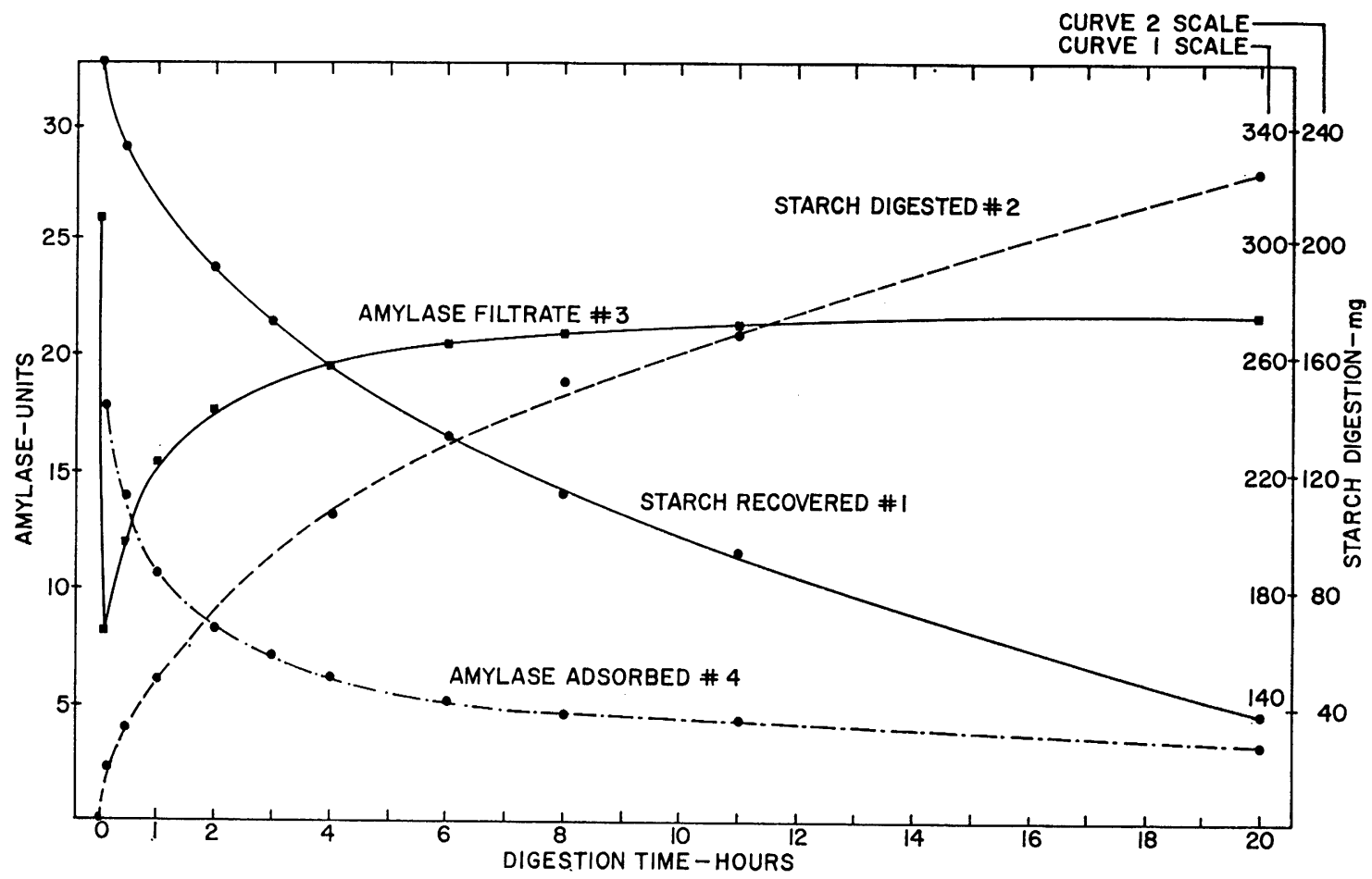

Fig. 1. Comparison of adsorption, desorption and digestion curves obtained during the action of 25.7 units of pancreatic $\alpha$-amylase on $363 \mathrm{mg}$ of maize starch. Curve 1; Starch remaining after intervals of time of action. Curve 2; Starch digested. Data of curve 1 subtracted from original 363 $\mathrm{mg}$ of starch. Curve 3; Alpha amylase (units) found in the filtrate after intervals of enzyme action. Curve 4; Alpha-amylase remaining adsorbed; desorption curve. Data of curve 3 subtarcted from the added 25.7 units.

RATE OF DIGESTION VS DESORPTION

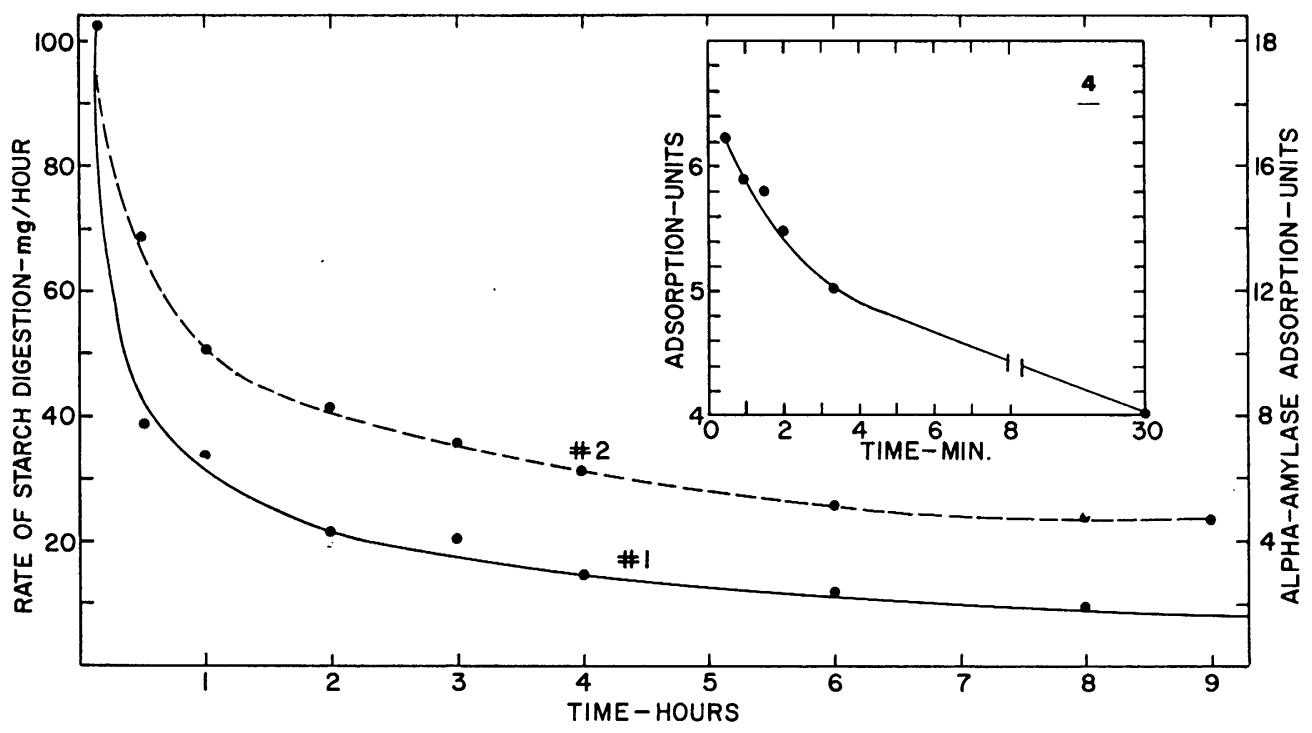

Fig. 2. Alpha-amylase desorption (curve 2) compared with the rate of digestion (curve 1). Inset curve 4 . The desorption curve of 6.2 units of pancreatic $\alpha$-amylase which was adsorbed by $400 \mathrm{mg}$ maize starch from 8.4 units of enzyme in 30 sec. 
(curve 2). This comparison emphasizes the possible eluting effect of the end-product oligosaccharides.

\section{Comparison of enzymes from different sources}

Sandstedt and Gates ${ }^{9}$ ) showed that $\alpha$-amylases from different sources differed markedly in their ability to digest maize starch. Fig. 3 shows similar data obtained by using a wide range of concentration of the $\alpha$-amylases from pancreatin, wheat malt, Bacillus subtilis, and Aspergillus oryzae on $363 \mathrm{mg}$ of raw maize starch. The digestion percent and units of enzyme adsorbed are plotted against the units of enzyme

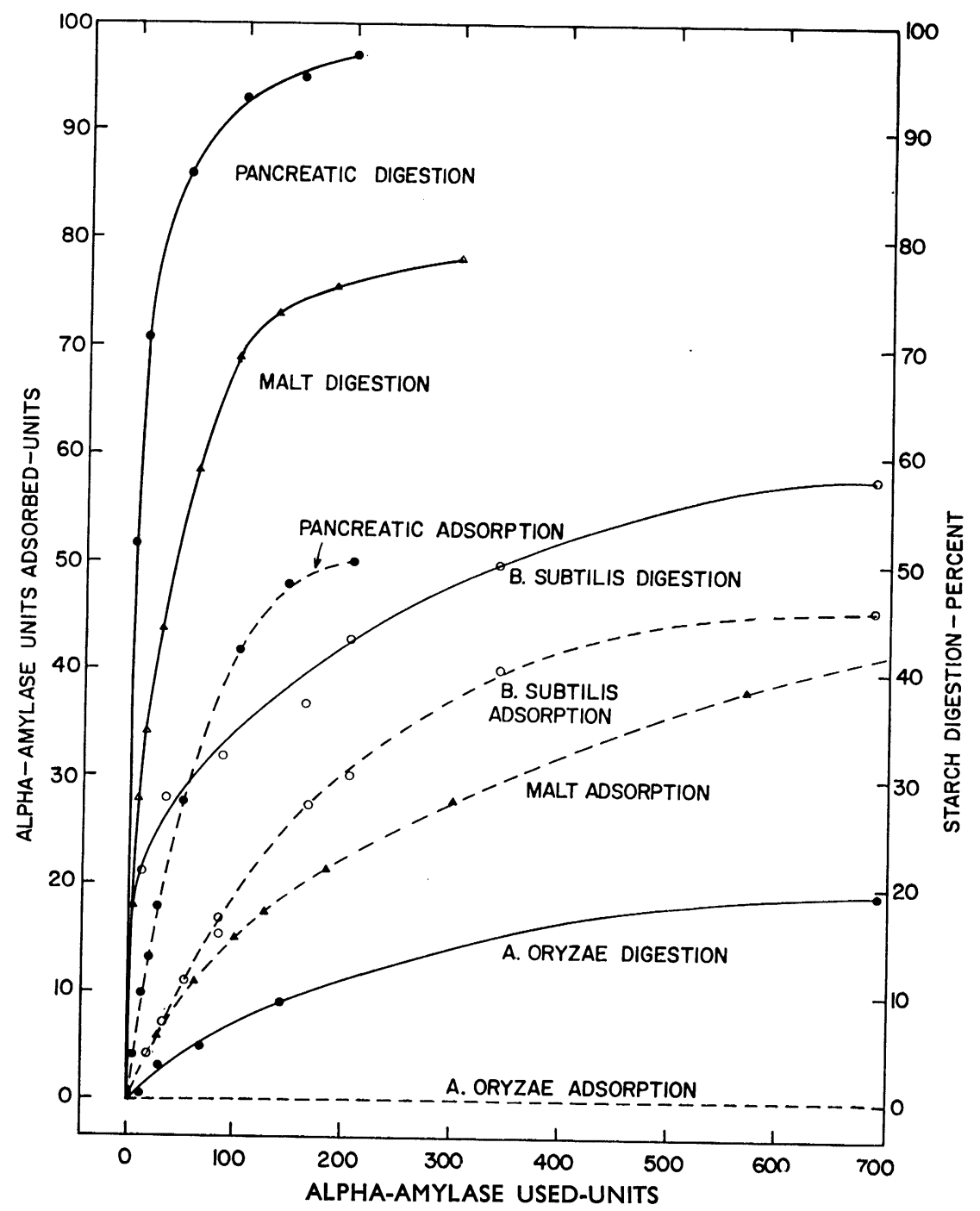

Fig. 3. Comparison of adsorption anddigestion as obtained from the action of increasing concentrations of pancreatic, malt, $B$. subtilis and $A$. oryzae $\alpha$-amylases on $363 \mathrm{mg}$ samples of maize starch. Adsorption at $10 \mathrm{~min}$, digestion after $20 \mathrm{hr}$. 
added. The digestion curves (solid line curves) illustrate the exceedingly great differences between these $\alpha$-amylases in their action on raw starch: On a 200 unit basis of enzyme used for a $20 \mathrm{hr}$ digestion period, the pancreatic enzyme digested $97 \%$ of the starch, malt $76 \%, B$. subtilis $43 \%$ and A. oryzae $12 \%$.

The adsorption curves are shown as broken lines (Fig. 3). The malt and $B$. subtilis adsorption curves reverse positions from those shown for digestion; the malt enzyme has a higher digestive action than the $B$. subtilis but the $B$. subtilis adsorbs more readily than the malt. Apparently the ability to adsorb on the starch does not necessarily indicate ability to digest the starch. The similarity of the $B$. subtilis adsorption pattern to its digestion pattern indicates a more close relation between adsorption and enzymatic activity for this enzyme than for the malt and pancreatic enzymes.

\section{Maximum digestions and adsorptions}

The slope of the $B$. subtilis digestion curve (Fig. 3) indicates that a maximum of digestion had been reached with the addition of 680 units of enzyme (or would have been reached with a little more enzyme or more time). Since $93 \%$ of the added enzyme was still active in the filtrate and there was $40 \%$ of the starch remaining undigested, the adsorbed enzyme would seem to have permanently filled all of the accessible adsorption sites on the raw starch and the active sites of the enzyme could no longer make contact for digestion on the granules (or possibly the active sites were inactive).

It seems that the same situation was rapidly approaching with the malt $\alpha$-amylase digestion curve indicating a possible maximun digestion of about $80 \%$ with the addition of 500 units of $\alpha$-amylase.

Surprisingly, considering the differences in the patterns of adsorption (Fig. 3), the adsorptions tended to level off to a relatively similar maximum; slightly over 50 units for the pancreatic, about 47 for the B. subtilis and 45 for the malt. Apparently the available "space" or the available binding sites on the starch granule were largely limited to a narrow range of units regardless of the source or activity of the units.

The adsorption of the $A$. oryzae $\alpha$-amylase was imperceptible under the conditions used for this research. Walker and $\mathrm{Hope}^{14}$ ) found no adsorption on raw starch for either $B$. subtilis or $A$. oryzae $\alpha$-amylases at $35^{\circ} \mathrm{C}$. They did find adsorption at $3^{\circ} \mathrm{C}$ with $B$. subtilis but not with $A$. oryzae. Apparently their methods were not sensitive enough to show the adsorption of $B$. subtilis $\alpha$-amylase at $35^{\circ} \mathrm{C}$. It seems probable that there was some adsorption of $A$. oryzae at $30^{\circ} \mathrm{C}$ but our methods were not sensitive enough to detect it. It is questionable if an adsorption of $1 \%$ of the enzyme would be detected. Small amounts of adsorbed $\alpha$-amylase may be quite effective.

Some of the data of Fig. 3 are replotted in Fig. 4 to show the relation of the adsorbed enzymes to digestion. In this figure the $\alpha$-amylase units adsorbed at 10 min are plotted against the $\mathrm{mg}$ of starch digested in one hour. Though a greater percentage of the added enzyme was adsorbed from the $B$. subtilis preparation, as noted in Fig. 3, the adsorbed malt enzyme was the more effective for digestion (Fig. 4). 


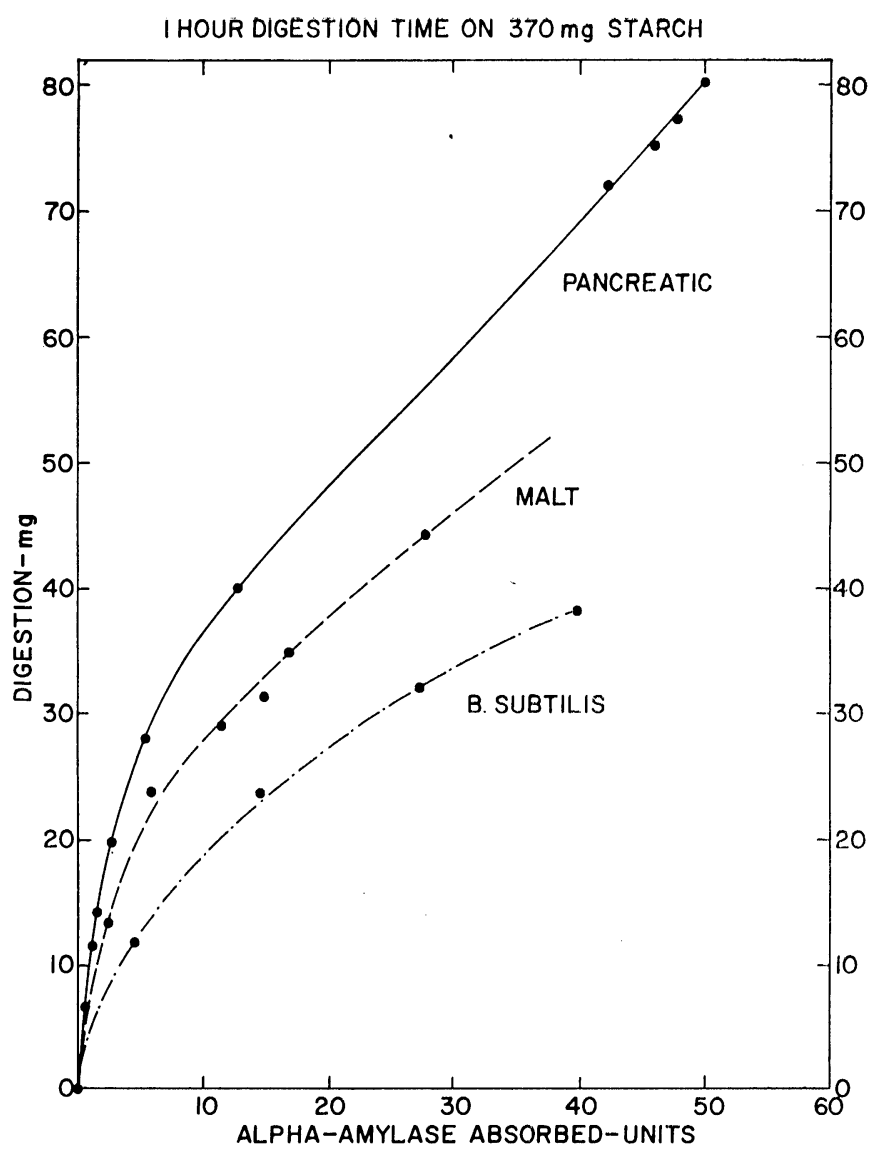

Fig. 4. Comparison of the digestions obtained from increasing concentrations of adsorbed pancreatic, malt and $B$. subtilis $\alpha$ amylases. Adsorption time $10 \mathrm{~min}$, digestion $60 \mathrm{~min}$.

The deceleration shown in the digestion curves of the three enzymes was in the reverse order of their activity. This indicates that the deceleration was not due to the endproducts of digestion. Apparently the enzyme adsorbed from very low concentrations had high activity on the raw starch but the activity decreased with additional adsorption; the greater the adsorption the less the activity per unit. According to the adsorption-digestion curves of Fig. 4, the effect of crowding was more effective on the less active $\alpha$-amylases. Possibly their conformation or flexibility is such that the adsorption sites as well as the active sites do not conform readily to the available sites on the raw starch granule and conforimty becomes more and more difficult with crowding. The data of Fig. 3 as discussed above suggest that when the adsorption sites on the starch were filled, the adsorbed enzyme had become inactive. The activity of the filtrate enzyme on $\beta$-limit dextrin and its inactivity on the raw starch suggest also that the adsorbed enzyme was permanently bound.

Another interesting interrelation between these enzymes and the efficiency of 


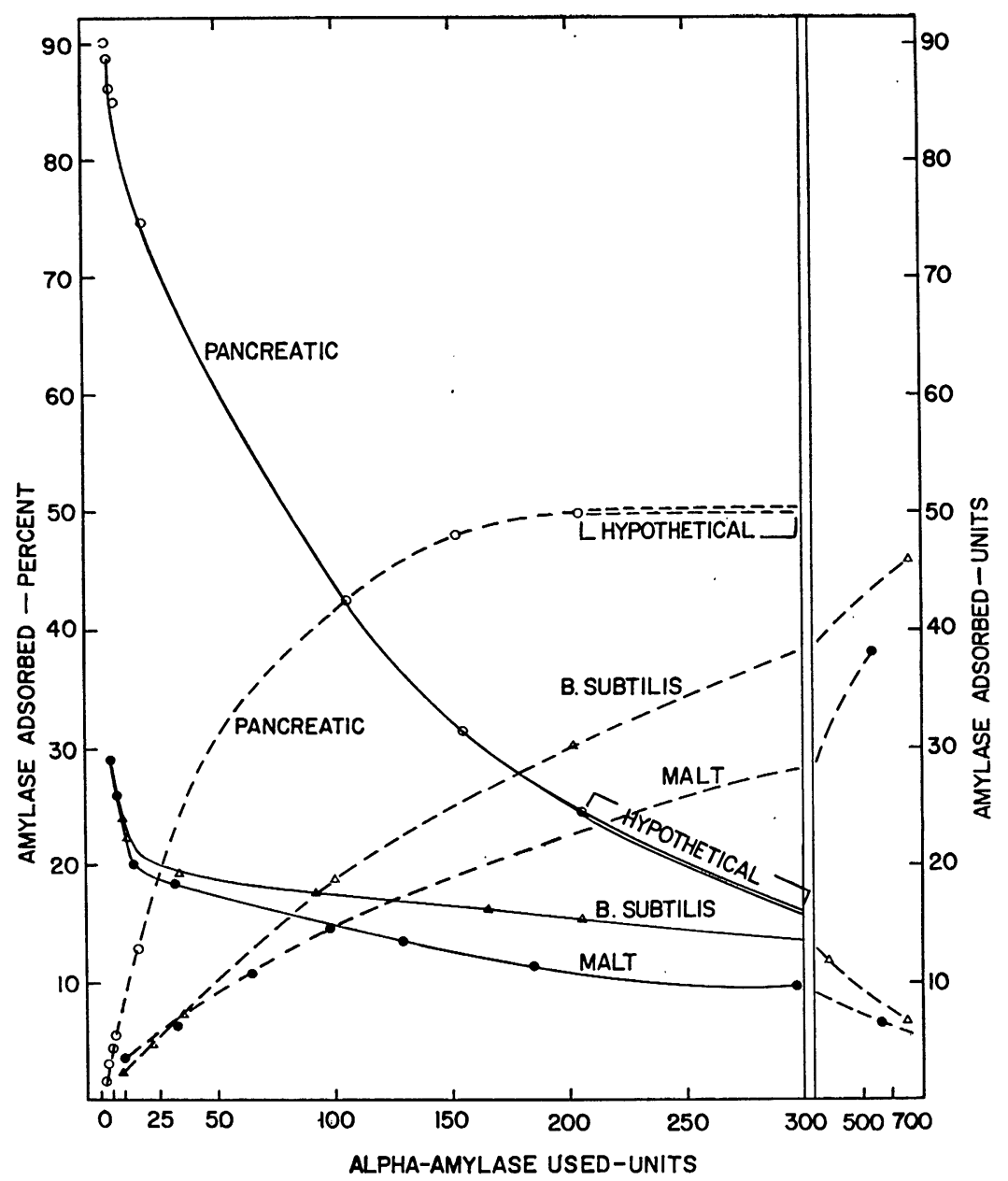

Fig. 5. Percent of enzyme adsorbed from increasing concentrations of pancreatic, malt and B. subtilis $\alpha$-amylases-solid lines, units adsorbed-broken lines. From the data of Fig. 3.

their adsorption may be made by plotting $\alpha$-amylase units added against percent adsorbed (Fig. 5). For contrast the curves showing units adsorbed are included. The percentage adsorption of $B$. subtilis $\alpha$-amylase from the addition of 25 to 300 units varied only from $14 \%$ to $19 \%$ whereas the variation of pancreatic $\alpha$-amylase over the same enzyme range of added enzyme was from $22 \%$ to $71 \%$.

The relatively low percent adsorption from small amounts added of the $B$. subtilis and malt $\alpha$-amylases compared to the somewhat similar percentage for larger amounts seem to indicate that the adsorption-sites on the raw starch were available (up to the 50 units maximum hypothesized previously) but $70 \%$ of the adsorption sites of the $\alpha$-amylase molecules were ineffective or perhaps $70 \%$ of the enzyme molecules have adsorption sites that do not conform to the sites on the raw starch molecule. 
The efficiency of the adsorption of the pancreatic $\alpha$-amylase decreases rapidly with increasing amounts of added enzyme; this may indicate the effects of crowding as the accessible sites on the raw starch granule are filled.

\section{Characteristics of the $p H$-adsorption and $p H$-digestion curves}

Sandstedt and Gates ${ }^{9}$ ) showed that the $\mathrm{pH}$ optima of the $\alpha$-amylases acting on raw starches were similar to the well established optima for digestion of boiled starch. It is of interest to show how these $\mathrm{pH}$-activity curves correlate with the $\mathrm{pH}$-adsorption curves. Fig. 6 shows a comparison of the $\mathrm{pH}$-adsorption and $\mathrm{pH}$-activity curves for

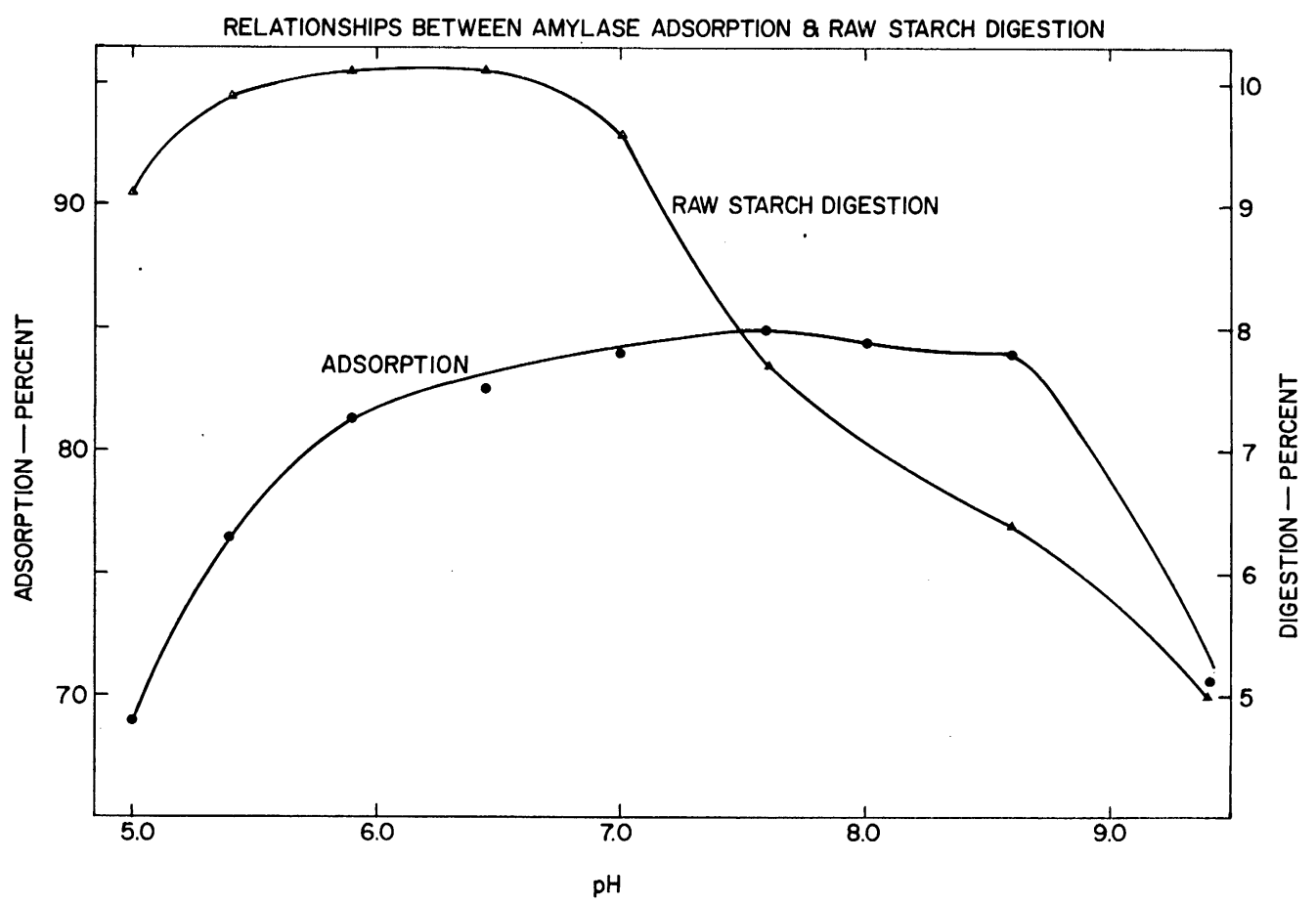

Fig. 6. Comparison of the $\mathrm{pH}$ curves for adsorption and hydrolysis by 25.7 units of pancreatic $\alpha$-amylase on $763 \mathrm{mg}$ of waxy-maize starch; $60 \mathrm{~min}$ periods of action.

25.7 SKB units of pancreatic $\alpha$-amylase acting on $763 \mathrm{mg}$ of raw waxy-maize starch for a $1 \mathrm{hr}$ period. These curves have little similarity; the optimum for digestion was between $\mathrm{pH} 5.9$ and $\mathrm{pH}$ 6.4, the optimum for adsorption was $\mathrm{pH}$ 7.6. The enzyme was stable, under the conditions used, over the range of $\mathrm{pH} 5$ to $\mathrm{pH}$ 8.6. Walker and Hope ${ }^{14)}$ obtained similar differences in $\mathrm{pH}$-adsorption and $\mathrm{pH}$-digestion curves. This was one of their reasons for concluding that adsorption and digestion were no related.

Fig. 7 compares the $\mathrm{pH}$ curves of adsorption and digestion for 2.4 units of $B$. subtilis $\alpha$-amylase acting on $750 \mathrm{mg}$ of waxy-maize starch for $1 \mathrm{hr}$. The curves are somewhat similar in shape but the $\mathrm{pH}$ optima differ considerably; $\mathrm{pH} 6.3$ for the 


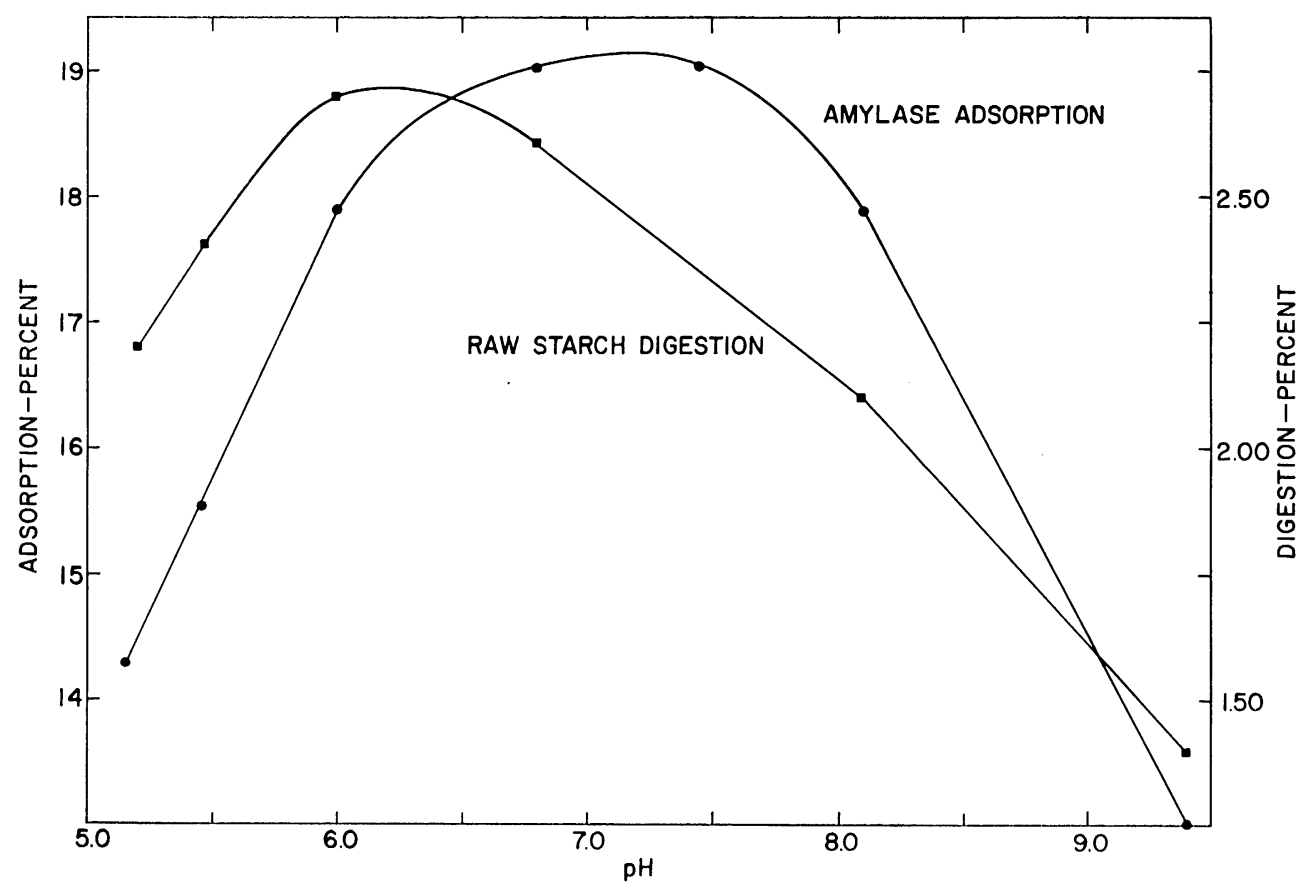

Fig. 7. The $\mathrm{pH}$ curves for adsorption and hydrolysis by 2.4 units of $B$. subtilis $\alpha$-amylase on $750 \mathrm{mg}$ waxy-maize starch; 60 min periods of action.

activity and between $\mathrm{pH} 6.8$ and $\mathrm{pH} 7.5$ for the adsorption. The enzyme lost activity above $\mathrm{pH} 8.1$.

Since the adsorption of $A$. oryzae on $360 \mathrm{mg}$ normal maize starch was imperceptible it was thought that it might have an appreciable adsorption if used on 750 mg of waxy-maize starch in the presence of $0.04 \%$ Roccal. ${ }^{9}$ ) Fig. 8 shows the pHactivity and $\mathrm{pH}$-adsorption curves for 14.7 units of $A$. oryzae $\alpha$-amylase acting on 750 $\mathrm{mg}$ of waxy-maize starch with and without $0.04 \%$ Roccal for $60 \mathrm{~min}$ for the adsorption curves and $20 \mathrm{hr}$ for the digestion. These curves are similar with no appreciable difference in $\mathrm{pH}$ optima. The Roccal increased both the adsorption and digestion. However, the adsorption on $750 \mathrm{mg}$ of waxy-maize starch without Roccal was imperceptible.

Adsorption and digestion on starches of different origin

Sandstedt et $a l .{ }^{9)}$ compared the digestibility of a number of raw starches from different plant sources including some of the so called "root" starches and some genetically modified maize starches. They found a wide spread in the digestibility ranging from $2 \%$ to $90 \%$. However, the $\alpha$-amylase adsorptions were not determined. It was thought desirable to supplement these data with information on the adsorptiondigestion relations in such a diverse group of starches.

Fig. 9 compares the data obtained from digestions on starches from different sources having widely differing characteristics. The data were obtained from the 


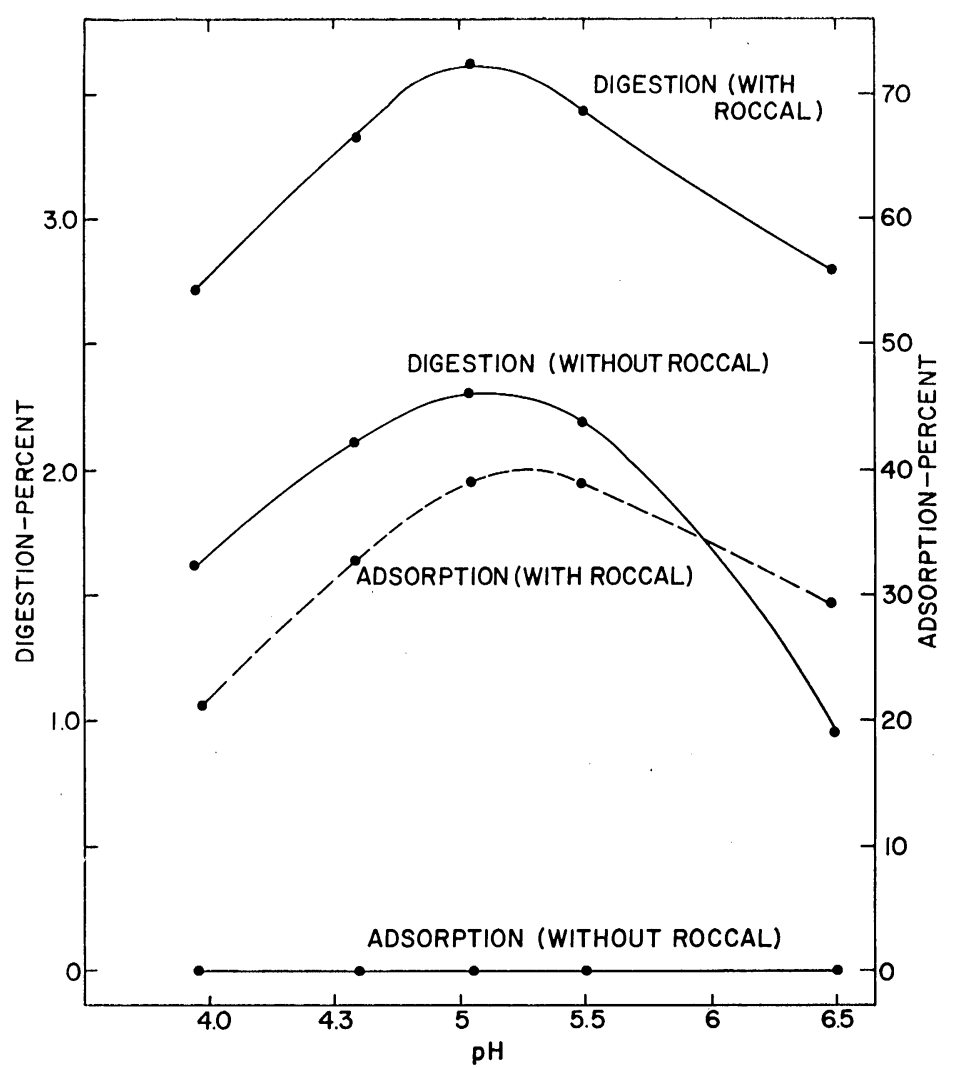

Fig. 8. The pH curves for adsorption and hydrolysis by 14.7 units of $A$. oryzae $\alpha$-amylase on $750 \mathrm{mg}$ waxy-maize starch with and without $0.04 \%$ Roccal; $60 \mathrm{~min}$ adsorption time, $20 \mathrm{hr}$ digestion time.

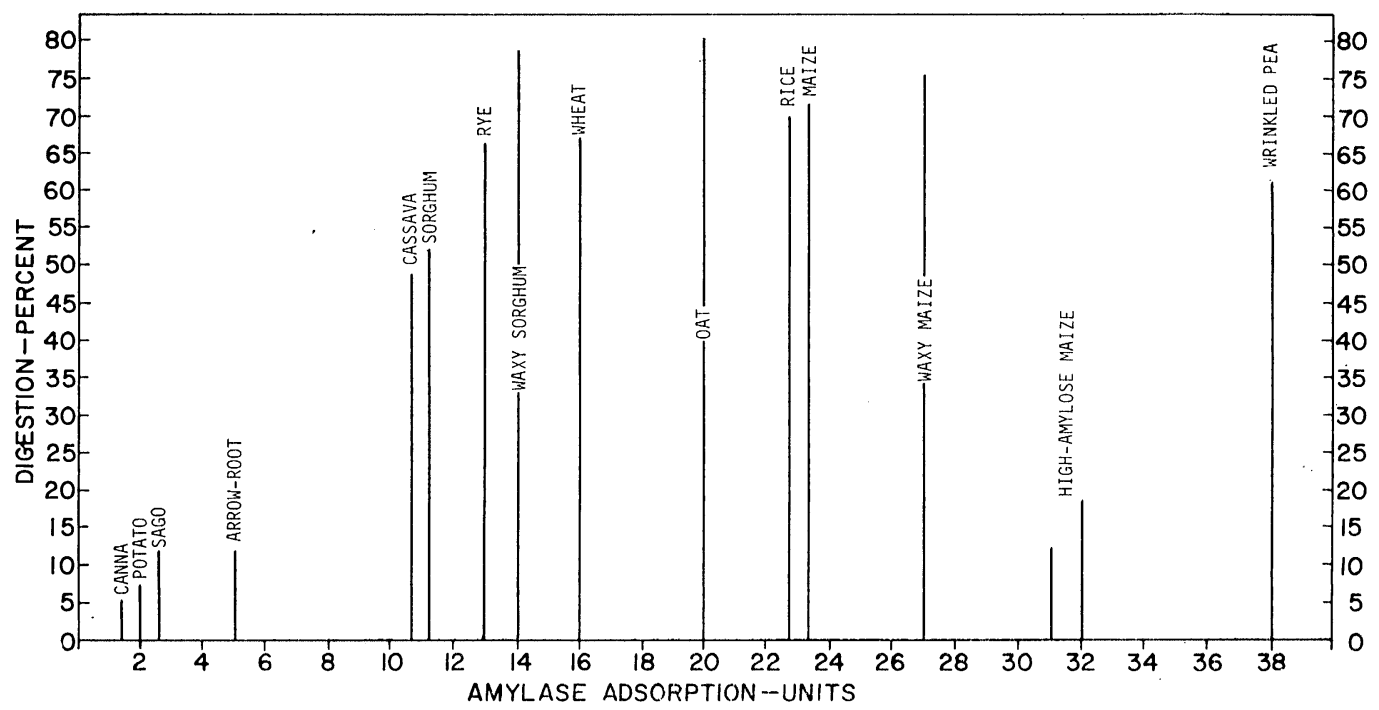

Fig. 9. Comparison of adsorption and digestion of $375 \mathrm{mg}$ samples of various starches by 180 units of malt $\alpha$-amylase. 
action of 180 units of malt $\alpha$-amylase on $375 \mathrm{mg}$ of starch. The digestion percents varied from $5 \%$ to $80 \%$. The "root" starches, with the exception of the cassava starch, had low adsorptions and correspondingly low digestions. The cassava was more similar to the cereal starches than to the other "root" starches. There was considerable variation in the ratio of adsorption to digestion among the cereal starches; the waxy-sorghum and oat starches were more susceptible to enzymatic action than the other cereal starches with comparable enzyme adsorption. Waxymaize had a relatively high adsorption and high digestibility. On the other hand, the two high-amylose maize starches had the highest adsorptions of the cereal starches but exceedingly low digestibility. The wrinkled pea starch, also a high-amylose starch, had the highest adsorption of all the starches but a relatively low digestion.

These data indicate that both the adsorbing sites and accessible sites for enzyme activity on the starch granule vary from one starch to another. It appears that the variation is such that the adsorbed enzyme may or may not have difficulty in conforming to the pattern required for activity.

The great differences in the adsorption and activity of the enzyme on these raw starches seem to suggest structural differences in the granules; differences in the pattern of intermolecular bonding. The intermolecular bonding in the "root" starches (e.g. potato) seems to quite effectively cover the potential adsorption sites. Whereas at the other extreme, in the high-amylose starches, the intermolecular bonding leaves the adsorption sites readily accessible to the enzyme but the sites at

Table I. Comparison of Adsorption and Digestibility Obtained from a Series of Starches By Three $\alpha$-Amylases

\begin{tabular}{|c|c|c|c|c|c|c|}
\hline \multirow{3}{*}{ Starch } & \multicolumn{6}{|c|}{ Enzymes and amounts used } \\
\hline & \multicolumn{2}{|c|}{$\begin{array}{c}180 \text { units } \\
\text { Malt } \alpha \text {-amylase }\end{array}$} & \multicolumn{2}{|c|}{$\begin{array}{c}350 \text { units } \\
\text { B. subtilis } \alpha \text {-amylase }\end{array}$} & \multicolumn{2}{|c|}{$\begin{array}{c}25 \text { units } \\
\text { Pancreatic } \alpha \text {-amylase }\end{array}$} \\
\hline & $\begin{array}{c}\text { units } \\
\text { adsorption }\end{array}$ & $\begin{array}{c}\% \\
\text { digestion }\end{array}$ & $\begin{array}{c}\text { units } \\
\text { adsorption }\end{array}$ & $\begin{array}{c}\% \\
\text { digestion }\end{array}$ & $\begin{array}{c}\text { units } \\
\text { adsorption }\end{array}$ & $\begin{array}{c}\% \\
\text { digestion }\end{array}$ \\
\hline Canna & 2 & 5 & - & - & 2 & 4 \\
\hline Potato & 2 & 6 & 7 & 4 & - & 5 \\
\hline Sago & 2 & 11 & 7 & 8 & 3 & 16 \\
\hline Arrow-root & 5 & 12 & 11 & 11 & 4 & 21 \\
\hline Cassava & 11 & 48 & 11 & 34 & 10 & 54 \\
\hline Sorghum & 11 & 52 & 11 & 28 & 11 & 56 \\
\hline Rye & 13 & 66 & 18 & 55 & 8 & 74 \\
\hline Waxy-Sorghum & 14 & 77 & 28 & 53 & 15 & 81 \\
\hline Wheat & 16 & 66 & 25 & 45 & 10 & 72 \\
\hline Oat & 20 & 80 & 28 & 52 & 11 & 77 \\
\hline Rice & 23 & 70 & 39 & 41 & 17 & 72 \\
\hline Maize & 23 & 72 & 39 & 49 & 17 & 75 \\
\hline Waxy-Maize & 27 & 75 & 77 & 63 & 21 & 87 \\
\hline High-amylose maize & 31 & 12 & 42 & 7 & 15 & 13 \\
\hline High-amylose maize & 32 & 18 & 53 & 10 & 18 & 27 \\
\hline Wrinkled pea & 38 & 61 & 70 & 58 & 19 & 63 \\
\hline
\end{tabular}


which activity may occur are covered; or the pattern of adsorption and action sites does not correspond with those of the enzyme.

The starches shown in Fig. 9 also were subjected to digestion by the pancreatic and $B$. subtilis $\alpha$-amylases. The data obtained are presented, along with those for malt, in Table I. Although the relative quantities of the enzymes used do not give satisfactory comparable values, the data give a rough picture of the complicated interrelations involved. The starches are placed in the order of increasing adsorption of the malt enzyme (as in Fig. 9). The values for adsorption of the other two enzymes fit into this order reasonably well. Each enzyme, having its own pattern of adsorption and digestion as discussed earlier, for the most part did not vary extensively from that pattern. High adsorption was related to high digestion, although, there were many exceptions such as that of the exceptionally high adsorption of $B$. subtilis $\alpha$-amylase on waxy maize which produced only $63 \%$ digestion. The exceptions should be confirmed by further work.

\section{Conclusions}

The relation of hydrolysis (digestion) of raw starch by $\alpha$-amylases to adsorption of the enzyme is complicated. It is dependent on the specific enzyme, its concentration, time of action and on the specific starch involved. Also other factors of the environment, such as temperature and $\mathrm{pH}$, affect the relationship. Accordingly, though the relation is close and direct, the hydrolytic activity of the enzyme is not predictable from the adsorption except under a specific set of conditions.

The adsorption of the enzyme on raw starch was rapid, reaching a maximum in less than $30 \mathrm{sec}$, and was desorbed at a decelerating rate with time and was similar to the activity curve. Since the activity curve also represents end-product production, it appears that the end-product production may be responsible for desorption. However, the percent of enzyme adsorbed decreased with increasing amounts of enzyme added; the curve was a decelerating curve. This is characteristic of enzyme reactions in general. The rate of deceleration was dependent on the specific enzyme and was more rapid the less active the enzyme. The percent activity of the adsorbed enzyme also decreased with increasing adsorption and the curve was a decelerating curve. Again the deceleration was more rapid the less active the enzyme. This is interpreted to indicate that these decelerations were not due to end-product oligosaccharides.

The ratio of adsorption to activity varied markedly with the enzyme used and also with the starch.

The relation of adsorption to hydrolysis seems to be a measure of the conformity of the enzyme, or its ability to adjust its conformation, to the pattern of accessible sites for adsorption and activity on the particular starch granule. The efficiency of the $\alpha$-amylase would depend on its flexibility, or ability to conform, to the less accessible sites and the less favorable patterns of sites of the particular raw starch substrate. 


\section{References}

1) Akabori, S., Hagihara, B. and Ikenaka, T., Proc. Japan Acad., 27, 350 (1951).

2) Blish, M.J., Sandstedt, R.M. and Mecham, D.K., Cereal Chem., 14, 605 (1937).

3) Gates, R. L. and Sandstedt, R.M., Cereal Chem., 30, 413 (1953).

4) Kneen, E., Sandstedt, R.M. and Hollenbeck, C.L., Cereal Chem., 20, 399 (1943).

5) Official Methods of the Assoc. Official Agri. Chemists, 9 th Ed. p 129. 10. 081 (1960).

6) Redfern, S., Cereal Chem., 24, 259 (1947).

7) Sandstedt, R.M., Kneen, E. and Blish, M.J., Cereal Chem., 16, 712 (1939).

8) Sandstedt, R.M., Jolitz, C.E. and Blish, M.J., Cereal Chem., 16, 780 (1939).

9) Sandstedt, R.M. and Gates, R.L., Food Research, 19, 190 (1954).

10) Sandstedt, R.M., Strahan, D., Ueda, S. and Abbott, R.C., Cereal Chem., 39, 123 (1962).

11) Schwimmer, S. and Balls, A.K., J. Biol. Chem., 176, 465 (1948).

12) Ueda, S., J. Agr. Chem. Soc. Japan, 31, 898 (1957).

13) Ueda, S., Proc. Int. Symp. Enzyme Chem., Tokyo and Kyoto, 491 (1957).

14) Walker, G. J. and Hope, P. M., Biochem. J., 86, 452 (1963). 